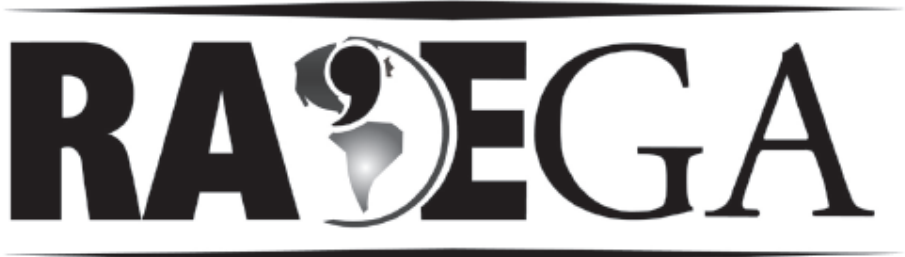

O ESPAÇO GEOGRÁFICO EM ANÁLISE

\title{
PROPOSTA DE ZONEAMENTO AMBIENTAL PARA O MUNICÍPIO DE ARROIO DO MEIO - RS ${ }^{1}$
}

\section{ENVIRONMENTAL ZONING PROPOSAL FOR THE CITY OF ARROIO DO MEIO - RS}

\author{
Bruna Letícia Thomas ${ }^{2}$
}

\section{RESUMO}

O município de Arroio do Meio, no Rio Grande do Sul, possui em seu território atividades econômicas de risco potencial de degradação, como, por exemplo, as práticas agrícolas intensivas. Diante disso, o objetivo do presente artigo é apresentar a proposta de zoneamento ambiental realizada para o município, de forma a contribuir com o desenvolvimento ordenado e racional, respeitando os condicionantes ambientais e os usos já consolidados no espaço de análise. Este zoneamento baseou-se na metodologia de Souza (2004), a partir do reconhecimento de cinco principais atributos (declividade, cobertura vegetal, recursos hídricos, aglomerações urbanas e intervenções antrópicas) e a identificação de áreas de incompatibilidade legal de APPs. Para isso, realizaram-se mapeamentos temáticos no software SPRING 5.0.6, trabalhos de campo e análise integrada dos resultados obtidos para a realização da proposição das zonas.

Palavras-chave: Zoneamento Ambiental; Diagnóstico Ambiental; Arroio do Meio - RS.

\footnotetext{
${ }^{1}$ Artigo resultante do Trabalho de Graduação Final desenvolvido sob orientação da Professora Drª Eliane Maria Foleto, Departamento de Geociências, Universidade Federal de Santa Maria.

${ }^{2}$ Geógrafa, Mestranda em Geografia pela Universidade Federal de Santa Maria. brunaths@hotmail.com
} 


\section{ABSTRACT}

The municipality of Arroio do Meio, Rio Grande do Sul, has economic activities in its territory potential risk of degradation, for example, intensive agricultural practices._There fore, the objective of this paper is to present the proposal of environmental zoning for the municipality performed in order to contribute to the orderly and rational, while respecting the environmental constraints and the uses already established in the space of analysis. This zoning was based on the methodology de Souza (2004), from the recognition of five main attributes (slope, vegetation, water resources, urban and human interventions) and identification of areas of legal conflict of APP. To achieve this objective is in thematic mapping software SPRING 5.0.6, fieldwork and integrated analysis of the results obtained for the realization of the proposition areas. Keywords: Environmental Zoning; Environmental Assessment; Arroio do Meio RS.

\section{INTRODUÇÃO}

O processo de apropriação e ocupação humana sobre a superfície terrestre, na maioria dos casos, não ocorreu de forma adequada. No decorrer do tempo, o homem usufruiu das características naturais do meio, modificando e reordenando seus aspectos, alterando seu equilíbrio e os fluxos de matéria e energia a partir das novas situações criadas, advindas do estabelecimento de suas atividades socioeconômicas. O homem, como agente modificador, altera as configurações espaciais de acordo com suas necessidades e interesses, provocando a quebra do equilíbrio no qual aquele meio estava integrado.

Decorrente da apropriação inadequada torna-se necessário aderir a uma reflexão visando orientar as decisões e ações futuras em relação às formas de uso espacial. Isto porque, hoje, após inúmeros problemas causados pela ocupação e apropriação desordenada, começa-se a entender e a considerar as leis e dinâmicas da natureza no estabelecimento das atividades, buscando que ocorra de forma ordenada, racional e sustentável (ROSS, 2003, p.12).

No Brasil, muitos municípios cresceram e se desenvolveram de acordo com seus interesses e necessidades, desconsiderando completamente os espaços e limites físico-naturais impostos, o que acabou por estabelecer inúmeros problemas sociais, políticos, econômicos e ambientais. Portanto, a busca pelo planejamento do espaço deve propiciar uma relação harmoniosa 
entre o homem e a natureza e, o zoneamento ambiental, como um de seus instrumentos, visa que o impacto da ocupação humana seja minimizado ao máximo a partir do estabelecimento de distintas zonas de uso e manejo dos atributos nelas existentes.

Como muitos outros municípios do país, Arroio do Meio, no estado do Rio Grande do Sul, não possui material cartográfico sobre seu meio físiconatural, importante ferramenta necessária às análises de planejamento e ordenamento territorial e ambiental. Visto que o município, juntamente com o Vale do Taquari, vem apresentando significativo crescimento, a presença de um instrumento de ordenamento territorial torna-se de grande valia, pois busca indicar o desenvolvimento municipal de forma ecologicamente equilibrada e visando qualidade de vida futura à população.

Sendo assim, considerando que o município possui em seu território atividades socioeconômicas de risco potencial de degradação, tanto pela supressão da vegetação quanto degradação de solos e recursos hídricos (exemplos: agricultura intensiva, indústrias e ocupação de áreas inadequadas), e que a Prefeitura Municipal carece de material técnico-científico referente a mapeamentos do espaço municipal, este estudo apresenta como objetivo principal elaborar uma proposta de zoneamento ambiental visando orientar os usos atuais e futuros do território municipal a partir da análise de algumas características físicas, naturais e antrópicas (diagnóstico ambiental). Desta forma, busca-se contribuir com o desenvolvimento futuro de Arroio do Meio, na medida em que este resultará em um material de utilidade ao planejamento e crescimento ordenado e sustentável do espaço municipal.

\section{ZONEAMENTO AMBIENTAL}

O termo zoneamento é utilizado para definir a compartimentação e delimitação de uma determinada região em distintas porções territoriais, obtidas através da avaliação de diferentes temas de acordo com os objetivos do estudo. Conforme estes e os critérios a serem avaliados para o estabelecimento das zonas, variadas nomeações ou adjetivações são 
agregadas ao conceito zoneamento, dentre elas: agrícola, agroecológico, ambiental, ecológico-econômico, industrial, de unidades de conservação, entre outros (SANTOS, 2004, p.132).

No Brasil, o termo zoneamento passou a ser recorrente a partir da década de 80, quando em 1981 é criada a Política Nacional de Meio Ambiente pela Lei o 6.938 de 31 de agosto. Entre os princípios e objetivos desta lei, constam a racionalização do uso do solo, o planejamento e fiscalização do uso dos recursos ambientais, recuperação de áreas degradadas, proteção de áreas ameaçadas, entre outras. Visando viabilizar esses princípios e objetivos, um dos instrumentos criados pela lei foi o zoneamento ambiental.

Este demorou a ser regulamentado pelo governo, ocorrendo somente em 2002 com o Decreto № 4.297, onde o zoneamento ambiental passa a ser denominado de zoneamento ecológico-econômico. Aqui, tratar-se-á do termo zoneamento ambiental, visto que, de acordo com as explicações de Santos (2004, p.135), esses dois termos não são considerados sinônimos, já que o zoneamento ecológico-econômico, adotado pelo governo brasileiro, possui uma maior preocupação com o desenvolvimento econômico e o zoneamento ambiental visa principalmente a preservação, reabilitação e recuperação da qualidade ambiental. Santos (2010, p. 02) complementa "O zoneamento ambiental é um instrumento que deve incorporar a variável ambiental no âmbito do ordenamento territorial de modo que as atividades humanas a serem desenvolvidas em determinado espaço sejam viáveis considerando aspectos ambientais e não somente do ponto de vista econômico".

Sendo assim, o zoneamento ambiental constitui-se em de um valioso instrumento de ordenação territorial visando o desenvolvimento sustentável e racional do espaço. Objetiva proporcionar de forma eficaz a conservação da natureza e seus recursos em harmonia com o desenvolvimento das atividades socioeconômicas. Para isso, o zoneamento considerará a importância ecológica, as potencialidades, limitações e fragilidades do espaço geográfico estudado. Assim, o zoneamento busca a melhoria e recuperação da qualidade ambiental e, consequentemente, da qualidade de vida populacional, a partir do 
estabelecimento de regimes especiais de uso pela ordenação do espaço em distintas zonas (também denominadas unidades de zoneamento).

Para a seleção e classificação destas, torna-se relevante 0 conhecimento acerca da área de estudo, afinal, a compartimentação das zonas ocorre a partir da análise dos atributos da área (SANTOS, 2004, p.128). Sendo assim, elas serão estabelecidas considerando as características relativamente homogêneas da paisagem e dos atributos avaliados. Portanto, as unidades de zoneamento irão diferenciar-se uma das outras pelas suas características próprias e, a partir disso, apresentarão distintos objetivos e normas para o desenvolvimento das atividades, manejo e conservação do meio.

O zoneamento ambiental é precedido/composto da fase de diagnóstico ambiental. Trata-se da análise da paisagem e dos atributos ambientais, permitindo assim conhecer as potencialidades e fragilidades da área de estudo a partir do levantamento das características da mesma, que posteriormente serão analisadas e consideradas no processo de zoneamento para 0 estabelecimento das zonas (SANTOS, 2004, p.35). Ross (2003) ressalta a importância do diagnóstico na busca pelo ordenamento territorial do espaço:

\footnotetext{
Não é preciso muito esforço para perceber que as ações elaboradas pelo homem no ambiente deveriam ser precedidas por um minucioso entendimento desse ambiente e das leis que regem seu funcionamento, e para isso é necessário elaborar-se diagnósticos ambientais adequados. Tal "radiografia ecológica" deve fornecer diretrizes as quais permitam imprimir modificações que minimizem os efeitos negativos através de medidas técnicas preventivas e ou corretivas (...) (ROSS, 2003, p. 12).
}

Conhecer a paisagem é de grande importância para melhor ocupá-la e dela fazer uso, e o diagnóstico permite visualizar as diferentes situações decorrentes da ocupação do solo pelo homem. Essa compreensão de como ocorre a organização e apropriação humana espacial permite buscar alternativas para solucionar problemas decorrentes de uma utilização errônea do meio, a fim de buscar melhores condições de vida à população e a garantia do meio ambiente ecologicamente equilibrado.

Portanto, o zoneamento deve buscar uma proposta de organização territorial, objetivando resolver ou minimizar os impactos decorrentes da 
inadequada ocupação e utilização do meio. Este instrumento visa sintetizar as informações a partir de uma análise integrada e crítica dos elementos analisados, buscando contribuir de forma positiva com o desenvolvimento do espaço estudado.

\section{LOCALIZAÇÃO E APRESENTAÇÃO DA ÁREA DE ESTUDO}

O município de Arroio do Meio, localizado no Vale do Taquari, apresenta como principal via de acesso a RS 130, possuindo limites administrativos com os municípios de Capitão e Encantado ao norte, Roca Sales e Colinas ao leste e sudeste, Estrela e Lajeado ao sul, e Marques de Souza e Travesseiro ao oeste (Figura no 1 ).

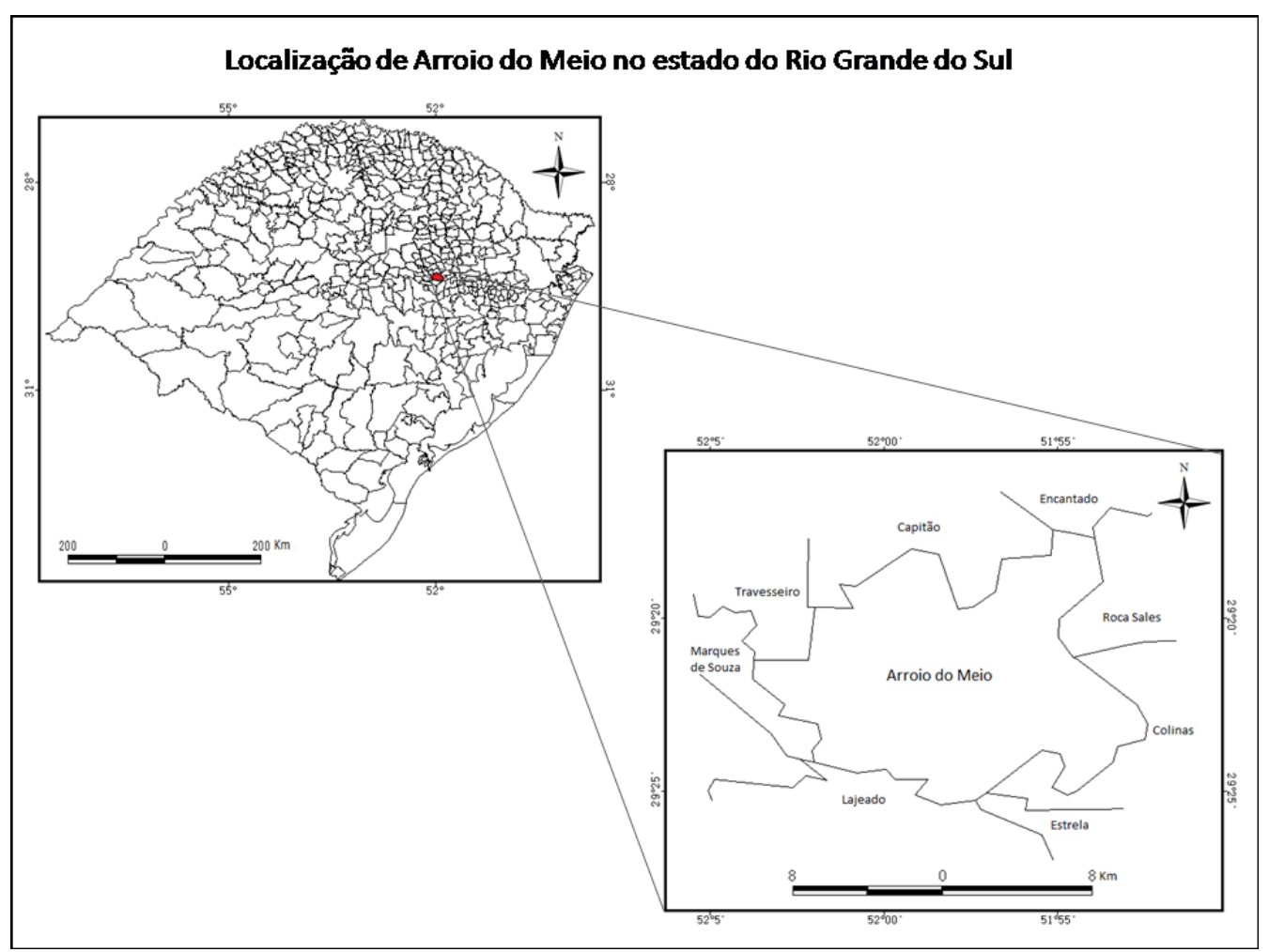

Figura no 1: Localização do município de Arroio do Meio no estado do Rio Grande do Sul. Elaboração: THOMAS, B. L., 2010.

Segundo o histórico disponibilizado pelo IBGE (2007, s/p), a primeira exploração às terras arroio-meenses foi realizada em 1653 por padres jesuítas. Entretanto, a colonização iniciou-se somente cerca de 200 anos depois, em 
1853, por imigrantes alemães e portugueses, período em que os núcleos populacionais teuto-brasileiros começaram a se organizar no Vale do Taquari. Em 1860, ocorre a fundação de São Caetano (hoje bairro do município) e em 1870 ocorre a fundação de Arroio do Meio (hoje sede).

A colonização do município assentou-se às margens do rio Taquari, ocorrendo de forma lenta pelo fato de que as famílias que ali possuíam terras, também possuíam em Lajeado (município mãe), estando estas em plena atividade. Portanto, mesmo dez anos após a sua colonização, Arroio do Meio não somava nem 10 famílias em seu território. A partir de 1872, a colonização se estende devido à vinda de mais colonos alemães, portugueses e também italianos. Esses, em sua maioria, estabeleceram-se nas partes de maior altitude, hoje pertencentes aos municípios de Nova Bréscia, Pouso Novo, Capitão e Travesseiro. Os colonos dedicavam-se principalmente às culturas do milho, feijão e trigo, produção que era escoada a Porto Alegre através dos Rios Taquari e Jacuí.

Em 28 de novembro de 1934, pelo Decreto № 5.759, Arroio do Meio torna-se município autônomo (se desmembrado de Lajeado e Encantado) e, em 2 de janeiro de 1935, o município é instalado oficialmente. Conforme estimativas de $1^{\circ}$ de Janeiro de 1956, o município possuía 27.050 habitantes, distribuídos em uma área de $494 \mathrm{~km}^{2}$. Desmembramentos municipais ocorreram nos anos de 1964 (Nova Bréscia), 1988 (Pouso Novo) e 1992 (Capitão e Travesseiro), diminuindo a população e o tamanho do município (IBGE, 2007).

Segundo o censo realizado em 2010, a população atual municipal é de 18.776 habitantes, o que significa um crescimento populacional de $9,72 \% \mathrm{em}$ relação ao ano de 2000, quando havia aproximadamente 16.951 habitantes. Atualmente, $25 \%$ da população é residente do perímetro rural e $75 \%$ residente do perímetro urbano. Com uma área territorial de $154 \mathrm{~km}^{2}$, a densidade populacional é de 121,92 hab/km² (IBGE, $2010 \mathrm{~s} / \mathrm{p}$ ).

Em 2007, Arroio do Meio consolidou-se pelo segundo ano consecutivo como a segunda economia do Vale do Taquari e entre os primeiros em PIB per capita $(R \$ 23.913,00)$. Os setores de indústria e comércio representam mais de 
$60 \%$ da economia municipal. A agricultura vem crescendo gradativamente, e hoje o município ostenta o 3 o lugar em abate de suínos do estado, destacandose também na produção de aves e bovinos para produção leiteira. Existem aproximadamente 1.965 propriedades agrícolas no município, sendo que as culturas de maior destaque são milho, soja, hortaliças, trigo e fumo (IBGE, 2007, s/p). Vale destacar que as atividades agrícolas do município são extremamente integradas com agroindústrias estabelecidas no município e região, como de laticínios, curtimento de couros e abate de suínos e aves.

Segundo os planos do governo do estado, o Vale do Taquari e, consequentemente Arroio do Meio, tende a crescer significativamente. $O$ RUMOS 2015 é uma política estadual que regionaliza o estado de acordo com suas características e potencialidades, sendo que, para o Vale do Taquari está previsto um grande crescimento agroindustrial. Essa região está sendo vista como a área de abastecimento alimentar da Região Metropolitana de Porto Alegre (GOVERNO DE ESTADO DO RIO GRANDE DO SUL, 2006, p.133). Diante disso, há uma tendência à maior industrialização e mecanização dos municípios do Vale e faz-se necessário pensar o homem neste espaço natural e também construído para que seu crescimento não ocorra de forma desordenada, provocando tanto impactos ambientais quanto sociais.

\section{METODOLOGIA}

Devido à necessidade de compreensão dos elementos dos meios físico, biológico e antrópico de forma integrada, a abordagem sistêmica torna-se a ideal para esta proposta de trabalho. Diante disto, frente ao objeto de estudo e da abordagem adotada, o método dessa pesquisa vem a ser o dedutivo. Este faz uso do raciocínio lógico, partindo da dedução do geral ao particular, na medida em que utiliza um modelo, neste caso a metodologia desenvolvida por Souza em 2004, para o desenvolvimento da pesquisa.

A construção do conhecimento deu-se principalmente a partir de leituras de artigos científicos, trabalhos de graduação, dissertações e o Plano Diretor Municipal de Arroio do Meio. Após a leitura desses, juntamente com o anseio 
de buscar fornecer um material geográfico e cartográfico ao município como auxílio ao planejamento do mesmo, os objetivos do trabalho foram sendo definidos. A partir disso, as leituras centraram-se nas temáticas de legislação, diagnóstico, zoneamento e planejamento ambiental.

A partir disso, destaca-se que, conforme Erse e Philomena (2005, p.52) existem várias metodologias sendo utilizadas em análises ambientais, entretanto, cada proposta metodológica difere de acordo com o território a ser considerado e os objetivos a serem alcançados. Além disso, baseado nas considerações de Santos (2010, p.7), optou-se por trabalhar com critérios entendidos como básicos para iniciar a discussão do zoneamento. Assim, trabalhou-se com alguns aspectos ambientais ligados ao meio físico, natural e antrópico que, como relata a citada autora, são considerados como critérios mínimos a serem tratados em um diagnóstico e seu zoneamento ambiental. Conforme Santos, 2010:

\footnotetext{
Visto como uma primeira proposta de aproximação do que se entende por um zoneamento ambiental, não foram considerados aspectos sociais e econômicos comumente envolvidos em sua elaboração, ainda que se entenda a amplitude do conceito "ambiental" envolvendo não apenas componentes físicos e biológicos, mas também sociais, econômicos e políticos (SANTOS, 2010, p. 26).
}

Neste estudo, tendo como objetivo orientar os usos a partir da análise das características físicas, naturais e antrópicas, optou-se pela metodologia de Souza (2004, p.134) para estabelecer as zonas, adaptada às metodologias desenvolvidas por Brandt e Sobreira, em 1994 e 1995, respectivamente.

Souza (2004, p.136) estabeleceu quatro distintas zonas tomando como temas de avaliação o meio físico (geomorfologia, neste caso as características clinográficas), a cobertura vegetal existente, as características gerais dos recursos hídricos, as aglomerações urbanas e as intervenções antrópicas (com destaque para as práticas agrícolas) e suas influências. Juntamente a esses temas, considera-se no processo de definição das zonas a aplicação da legislação vigente sobre Áreas de Preservação Permanente (APPs) de recursos hídricos, envolvendo suas nascentes e margens, conforme artigo $2^{\circ}$ da Lei 4.771/65, que instituiu o Código Florestal Brasileiro. 
As quatro zonas propostas pelo referido autor e adotadas neste trabalho são Zona de Interesse de Proteção Ambiental, Zona de Interesse de Controle Ambiental, Zona de Interesse de Reabilitação Ambiental e Zona de Interesse de Adequação Ambiental. Os principais critérios de avaliação para o estabelecimento de cada zona foram baseados nas considerações do citado autor, entretanto, algumas alterações foram necessárias para adequação à realidade do município de Arroio do Meio (Quadro no 1 ):

\section{Zona de Interesse de Proteção Ambiental}

Características principais: Apresenta a maior parte da área coberta por vegetação de mata densa e preservada, áreas de maior fragilidade ambiental (maiores declividades), recursos hídricos não degradados, inexistência de aglomerações urbanas e atividades humanas rarefeitas. Presença de maior número de áreas protegidas, como as áreas de preservação permanente.

Objetivos: Máxima proteção dos atributos presentes nessa zona.

\section{Zona de Interesse de Controle Ambiental}

Características principais: Cobertura vegetal de matas remanescentes, presença de atividades agrícolas, aglomerações rurais de pequeno porte, recursos hídricos em bom estado de conservação.

Objetivos: Manutenção da cobertura vegetal existente, assim como da qualidade dos recursos hídricos. Preocupação com um manejo racional dos atributos ainda existentes. Busca do manejo racional dos recursos naturais.

\section{Zona de Interesse de Reabilitação Ambiental}

Características principais: Alteração total da cobertura vegetal (vegetação rarefeita), atividades antrópicas intensas, principalmente relacionadas ao uso da terra (pastagens e culturas), recursos hídricos em estado regular ou ruim de conservação. Possibilidade de reversibilidade dos principais impactos existentes.

Objetivos: Buscar a recuperação de algumas áreas, como as áreas de preservação permanente e também a reabilitação dos recursos hídricos degradados.

\section{Zona de Interesse de Adequação Ambiental}

Características principais: Remoção total da cobertura vegetal original, alteração do meio físico (edificações, pavimentação, aterramentos...), degradação dos recursos hídricos (lixo, esgotamento sanitário, erosão...), atividades antrópicas intensas relacionadas às atividades urbanas, como indústrias e comércio.

Objetivos: Adequar as atividades diminuindo seu impacto ambiental, buscando o ajustamento de questões que causem impactos ambientais significativos.

Quadro no 1: Os critérios do zoneamento ambiental.

Baseado em: SOUZA, 2004, p. 136.

Em relação à parte técnica do trabalho, para o zoneamento foi utilizada a base cartográfica na escala 1:50.000 das cartas topográficas Lajeado e Marques de Souza (de nomenclatura SH.22-V-D-II-3 MI-2952/3 e SH.22-V-D-I4 Ml-2951/4), ambas de 1980 e elaboradas pela Diretoria do Serviço Geográfico do Ministério do Exército Brasileiro, e o software SPRING 5.0.6, 
desenvolvido pelo Instituto Nacional de Pesquisas Espaciais - INPE. O resultado final dos mapeamentos temáticos é apresentado em escala 1:110.000.

A etapa inicial foi o georreferenciamento das cartas para posterior realização do seu mosaico. Sucedendo a isso, ocorreu a sobreposição do limite municipal em formato shape disponível no banco de dados do IBGE. Esse limite foi verificado e corrigido segundo a Lei oㅜ 916/1993 que atualiza os limites municipais de Arroio do Meio.

A partir da disponibilidade desta base cartográfica (georreferenciada, mosaicada e com os limites do município), foi realizado o processo de digitalização das curvas de nível equidistantes (20 metros), cotas altimétricas com os referidos valores e rede de drenagem.

O mapeamento da rede hidrográfica foi realizado a partir da digitalização das informações presentes nas cartas topográficas de escala 1:50.000. Os rios Forqueta e Taquari, por serem de grande porte e de abrangência regional e estadual foram digitalizados com linhas mais espessas, de forma a demonstrar que recebem grande número de tributários, das mais distintas ordens. Juntamente com a rede hidrográfica, foram representadas as ilhas fluviais presentes nos citados rios.

O mapa de altimetria foi baseado na digitalização das curvas de nível com seus referidos valores altimétricos. As classes foram estabelecidas de 100 em 100 metros, o que proporcionou a geração de seis variáveis altimétricas. Buscou-se a utilização de uma escala gradual de cores para facilitar a visualização das distintas classes no mapa.

No mapeamento clinográfico, ou de declividade, avalia-se as curvas de níveis, quanto mais próximas forem estas, maior será a inclinação do relevo. A metodologia foi baseada em De Biase, que definiu os limites das cinco classes em porcentagem considerando usos e ocupações urbanas e rurais e a legislação florestal: 0 - 5\%, 5 - 12\%, $13-30 \%, 30-47 \%$ e maior de $47 \%$ (DE BIASE, 1992, p.51).

Já as Áreas de Preservação Permanente (APPs) dos recursos hídricos foram estabelecidas conforme o previsto no Código Florestal de 1965 (lei oㅡ 
$4.775 / 1965)$, onde os cursos d'água com largura inferior a 10 metros tiveram suas áreas de preservação mapeadas em 30 metros de largura. Os cursos d'água maiores, neste caso, os rios Forqueta e Taquari que, respectivamente apresentam largura média de 60 e 180 metros, foram enquadrados em APPs de 100 metros de largura. Além disso, todas as nascentes de cursos d'água tiveram suas áreas de preservação de 50 metros de raio, também prevista na mesma lei.

Para o mapeamento de uso e ocupação do solo, as bandas 3,4 e 5 da imagem de satélite Landsat TM de resolução 30 metros, datada em 13 de abril de 2009, foram utilizadas. A classificação da imagem ocorreu pelo método visual, ou seja, a partir da interpretação visual da imagem as classes temáticas foram digitalizadas.

Assim, para o mapeamento de uso e ocupação do solo as classes temáticas trabalhadas foram vegetação, mancha urbana e uso agrícola. Para vegetação, foram consideradas todas as manchas vegetacionais identificadas. Pela qualidade e escala da imagem, possivelmente algumas manchas de vegetação de mata exótica (eucalipto) foram incluídas nessa classe devido à dificuldade de distinção da vegetação nativa em relação à plantada, pelo fato destas ocuparem áreas muito pequenas. Para mancha urbana, foram consideradas áreas pavimentadas e com edificações residenciais, comerciais e industriais. Já no uso agrícola, as pastagens, o solo exposto para plantio, algumas manchas de eucalipto de visualização mais evidente, as culturas agrícolas e as pequenas casas dispersas entre essas áreas, foram classificadas.

Para o reconhecimento das áreas de incompatibilidade legal das APPs de recursos hídricos, foi realizada a sobreposição dos planos de informação uso e ocupação do solo e APPs. A partir disso, trabalhos de campo foram realizados para o registro fotográfico de algumas áreas onde se verificava 0 descumprimento da legislação ambiental pertinente às mesmas.

No processo de mapeamento e delimitação das zonas ambientais considerou-se os critérios de avaliação citados. A partir da análise integrada destes, realizou-se o mapeamento pela classificação visual (assim como no 
mapa de uso e ocupação do solo), ou seja, pela sobreposição dos planos de informação dos temas de avaliação e análise visual para sua classificação. Destaca-se que os limites das zonas não foram traçadas aleatoriamente, seguindo alguns preceitos: a Zona de Interesse de Proteção Ambiental teve como seu limite a curva de nível de 300 metros na porção ao sul e 160 metros na porção ao norte. A linha de transição entre as classes vegetação e uso agrícola foi usada na delimitação entre as zonas de Interesse de Controle Ambiental e Interesse de Reabilitação Ambiental. Já a Zona de Interesse de Adequação Ambiental teve como limitante a mancha urbana e áreas verdes adjacentes, ou seja, as APPs, dos arroios do Meio e Grande e rio Taquari, isso porque, como se tratam de áreas urbanas já consolidadas, a reabilitação das APPs destas torna-se praticamente impossível, restando a alternativa de adequar os usos para garantir melhorias da situação.

Destaca-se também que devido à alternância de usos agrícolas e urbanos próximo à RS 130, a Zona de Interesse de Adequação Ambiental tornou-se fragmentada resultante dessa descontinuidade de usos. Além disso, nem todas as manchas urbanas identificadas no mapa de uso e ocupação do solo do município foram classificadas na citada zona, pois muitas manchas isoladas e de menores proporções constituem-se de pequenas localidades no interior de Arroio do Meio, com presença de residências e pequeno comércio local.

Pelos critérios de avaliação propostos por Souza, somente foram utilizados de forma direta para a análise visual no processo de proposição das zonas dois dos quatro mapas elaborados. O mapa clinográfico foi utilizado para avaliação das declividades do município e a cobertura vegetal, as aglomerações urbanas e as influências antrópicas foram avaliadas a partir do mapa de uso e ocupação do solo.

O mapa de recursos hídricos foi utilizado para o mapeamento das APPs e auxiliou na realização dos trabalhos de campo para registro fotográfico e avaliação visual das condições dos mesmos, sendo consideradas as condições de conservação/degradação (principalmente presença/ausência de lixo e esgoto, condições das margens e seus usos). 


\section{RESULTADOS E DISCUSSÕES}

\section{DIAGNÓSTICO AMBIENTAL DO MUNICÍPIO DE ARROIO DO MEIO Caracterização hidrográfica municipal}

Conforme pode ser visualizado no mapa ํㅡ 1, dentre as características hidrográficas do município de estudo, verifica-se a presença de duas configurações de arranjos espaciais dos recursos hídricos: o padrão de drenagem paralelo e o dendrítico. As drenagens paralelas são mais comumente encontradas, decorrentes da existência de vertentes com acentuadas declividades que provocam o espaçamento regular entre as diferentes drenagens e, portanto, favorecendo este padrão. Além disso, em relação à hierarquia fluvial, encontram-se no território municipal canais de até terceira ordem, onde a largura dos mesmos não ultrapassa 10 metros. Os rios Forqueta e Taquari apresentam larguras médias de 60 e 180 metros, respectivamente.

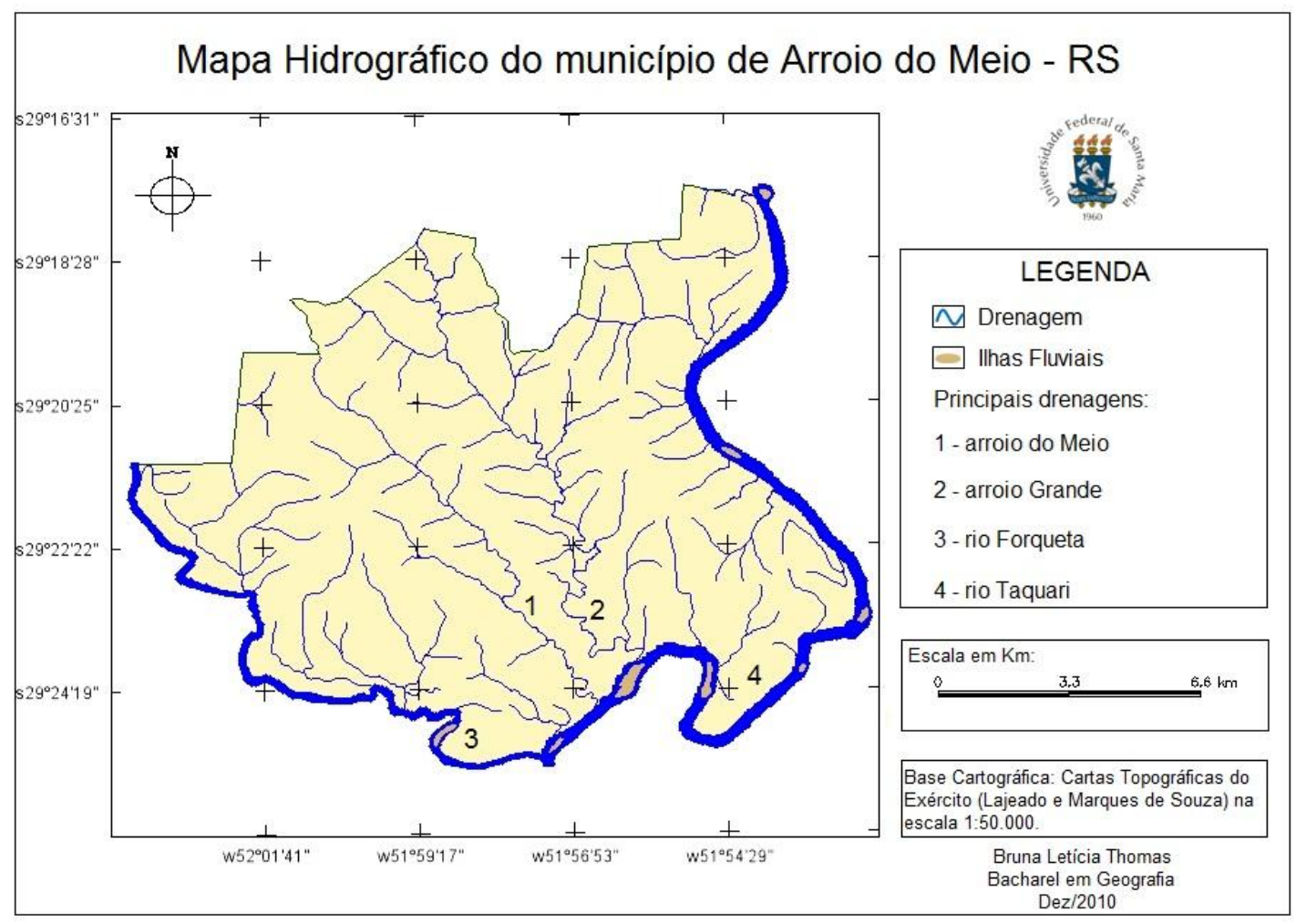

Mapa no 1: Mapa Hidrográfico do município de Arroio do Meio, RS. Elaboração: THOMAS, B. L., 2010. 
Já em relação ao tipo de canal, os arroios do Meio e Grande, em seu baixo curso, apresentam meandros, como pode ser visualizado pela formação de curvas sinuosas. Os rios Forqueta e Taquari também se apresentam meândricos em seu baixo curso, entretanto, em seu alto e médio curso, em municípios localizados ao norte de Arroio do Meio, situam-se encaixados em vales.

No município de estudo, esses rios, por já estarem em seu baixo curso e áreas de declividades menores, apresentam velocidade de escoamento baixa, favorecendo o processo de sedimentação fluvial e a ocorrência da deposição de cascalhos nas margens e a formação de ilhas fluviais, algumas destas já consolidadas, como pode ser percebido pela vegetação presente nas mesmas.

Em relação aos processos de inundação, o município sofre constantes perdas econômicas em períodos de excesso pluviométrico. Os rios Taquari e Forqueta e os arroios do Meio e Grande (mais próximos ao centro urbano), provocam prejuízos na agricultura de várzea e invadem casas, indústrias e estabelecimentos comerciais da área urbana. Além disso, a situação de alguns recursos hídricos próximos ao centro urbano é de degradação em alguns pontos, decorrente da deposição irregular de resíduos sólidos e esgotamento sanitário. Já no rural, os recursos hídricos sofrem com a degradação das APPs e, em vários casos, recebimento de dejetos animais.

\section{Caracterização altimétrica municipal}

Segundo a Carta Geomorfológica de Caxias do Sul (2003, s/p), Arroio do Meio situa-se na transição de duas regiões geomorfológicas: o Planalto das Araucárias e a Planície Continental. Essa situação justifica a variabilidade altimétrica do município, que possui cota mínima de 20 metros e cota máxima de 559 metros, esta no morro Gaúcho (Fotografia no 1). A situação de transição geomorfológica do município também é evidenciada por sua área $\left(\mathrm{em} \mathrm{km}^{2}\right) \mathrm{e}$ valor proporcional (em \%), como pode ser visualizado no quadro abaixo: 


\begin{tabular}{|c|c|c|}
\hline Classe Altimétrica & Área em $\mathbf{k m}^{\mathbf{2}}$ & Valor em \% \\
\hline Até 100 metros & 81,84 & 53,52 \\
\hline $100-200$ metros & 25,39 & 16,63 \\
\hline $200-300$ metros & 21,4 & 14,02 \\
\hline $300-400$ metros & 17,43 & 11,42 \\
\hline $400-500$ metros & 6,20 & 4,06 \\
\hline Mais de 500 metros & 0,35 & 0,23 \\
\hline
\end{tabular}

Quadro no 2: Classes altimétricas com seus respectivos valores. Elaboração: THOMAS, B. L., 2010.

Como é possível perceber, o município de Arroio do Meio encontra-se dividido altimétricamente, pois cerca de $53 \%$ da área total do município situa-se a até 100 metros de altitude, e as outras cinco classes totalizam aproximadamente $47 \%$ da variabilidade de altitude. O gradativo aumento de altimetria a partir da cota de 100 metros demonstra a situação de transição de regiões geomorfológicas no município, como é possível visualizar no Mapa no 2.

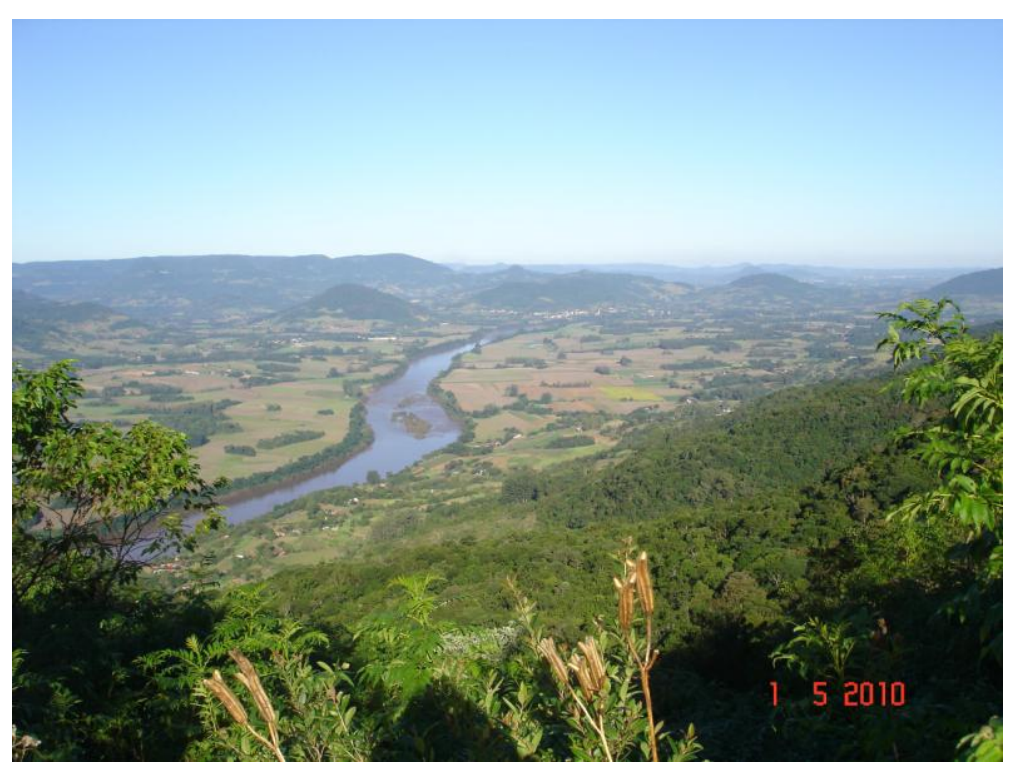

Fotografia no 1: A partir do morro Gaúcho, ponto mais alto do município, avistando o rio Taquari e sua planície de inundação, com cota altimétrica entre 20 e 40 metros.

Fonte: THOMAS, B.L. Passeio ao morro Gaúcho, maio de 2010. 


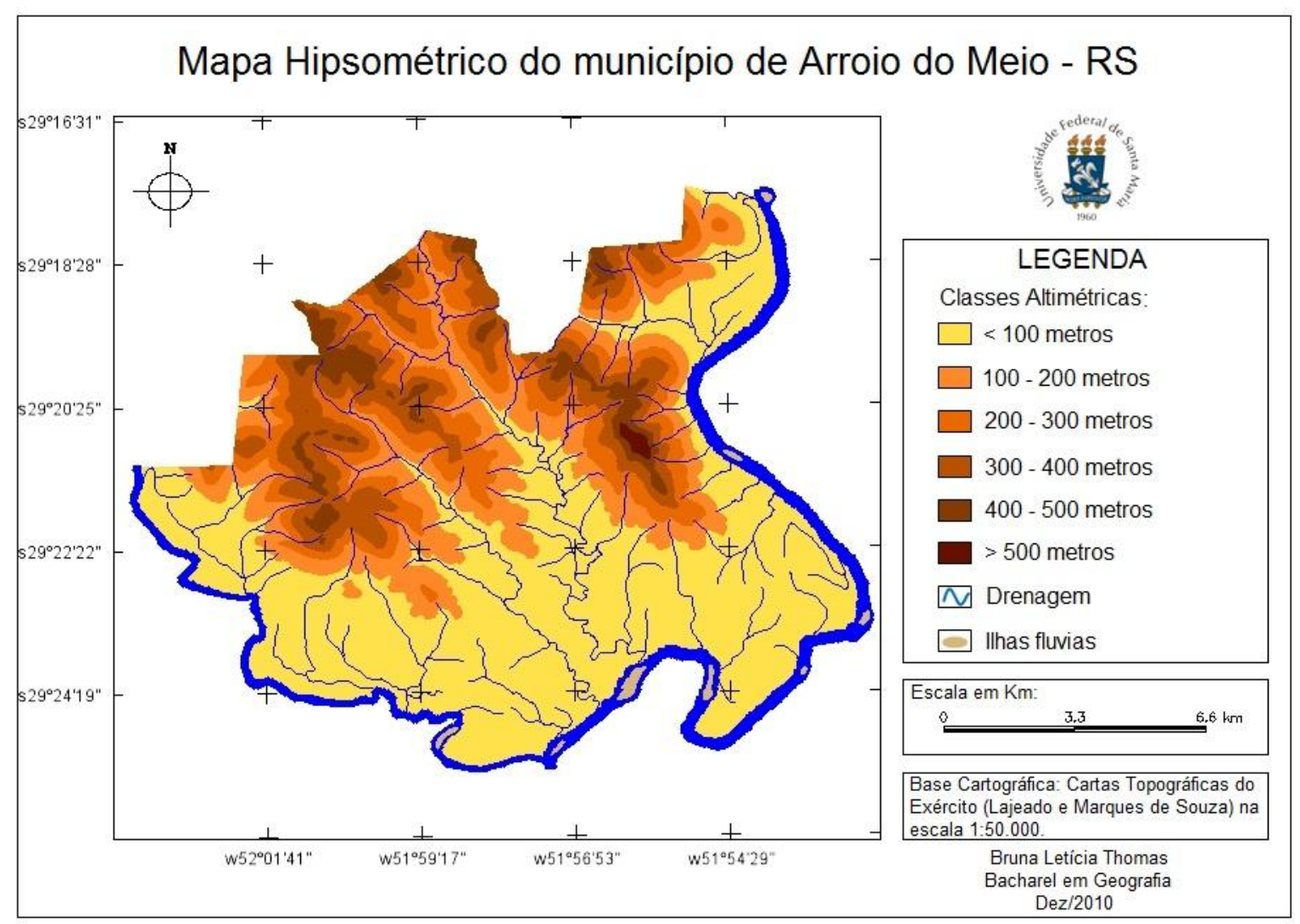

Mapa n 2: Mapa Hipsométrico do município de Arroio do Meio, RS.

Elaboração: THOMAS, B. L., 2010.

\section{Caracterização clinográfica municipal}

A situação clinográfica de Arroio do Meio também pode ser explicada pela transição de região geomorfológica, pois da Planície Continental para o Planalto das Araucárias transita-se de uma área relativamente plana no sul do município para uma área movimentada ao norte. Esta, decorrente da dissecação fluvial, apresenta vales encaixados e conjuntos de morros alongados e estreitos. Essa conformação do relevo condiciona declividades acentuadas, como é possível perceber no mapa de declividades ( $n$ - 3).

Analisando as declividades presentes, percebe-se que as mesmas foram determinantes para a ocupação do espaço municipal. As áreas com declividades acentuadas, presentes mais ao norte do município, apresentam significativa cobertura vegetal, pelo fato da prática agrícola ser dificultada 
nessas áreas, estando restritas a patamares de morros, onde as declividades são mais suaves em relação às demais. Nas planícies de inundação dos rios Forqueta e Taquari e alguns outros arroios, predominam áreas com declividades inferiores a $5 \%$ e solos mais profundos, o que implicou na ocupação destas para o uso da agricultura.

Em relação à legislação municipal de parcelamento do solo urbano (lei no 2.491/2006), destaca-se que não há ocorrência de ocupação urbana em declividades iguais ou superiores a 30\%. Entretanto, conforme De Biase (1992, p.51), a ocupação de áreas de até $5 \%$ de declividade junto aos recursos hídricos não é indicada devido ao risco a processos de inundação e foi justamente nessa condição que se desenvolveu grande parte da estrutura urbana municipal, fazendo com que essa sofra constantemente com inundações.

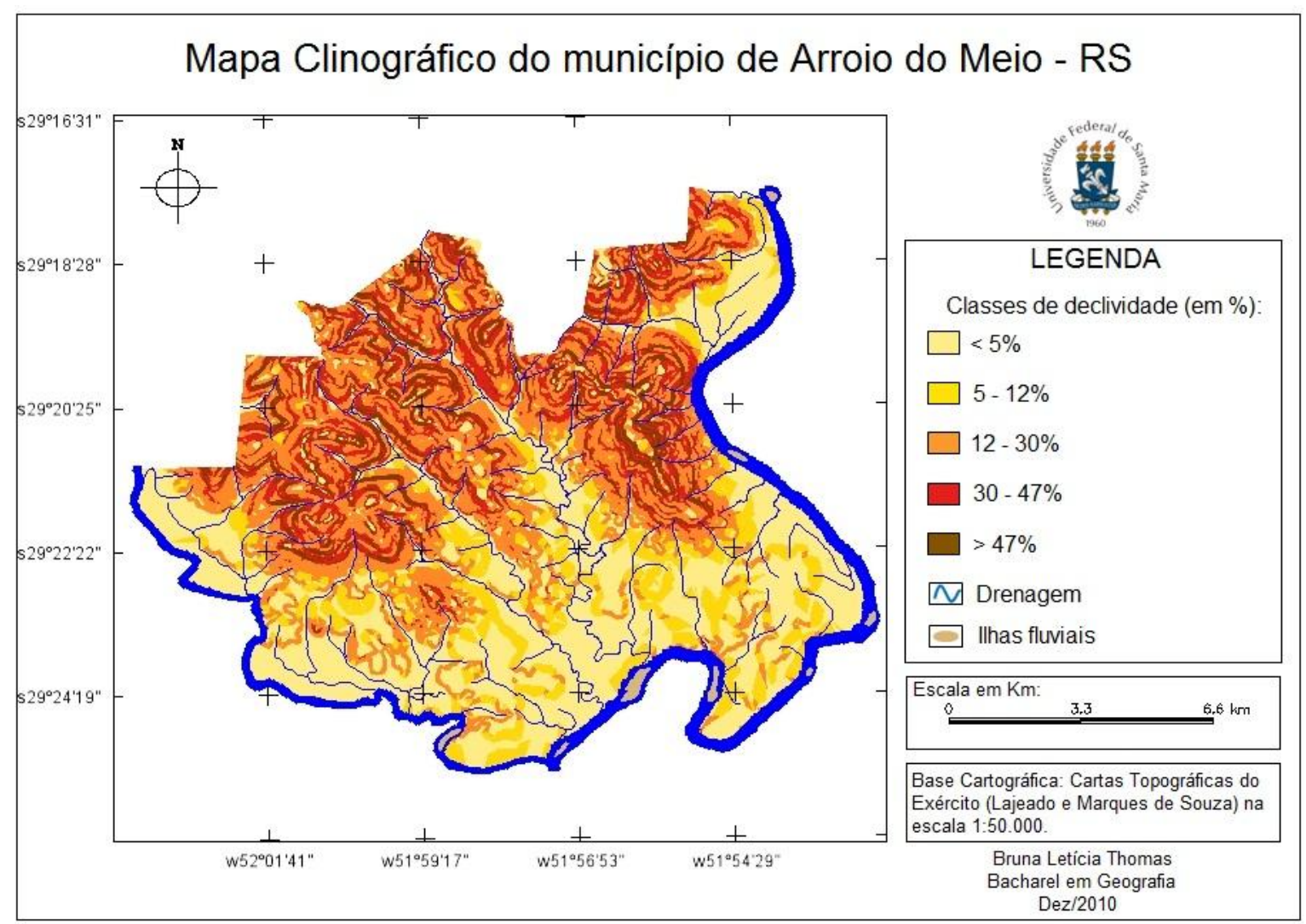

Mapa no 3: Mapa Clinográfico do município de Arroio do Meio, RS.

Elaboração: THOMAS, B. L., 2010. 


\section{Caracterização de uso e ocupação do solo}

Como já comentado anteriormente, as características de uso e ocupação do solo do município de Arroio do Meio (Mapa oㅜ 4) são bastante influenciadas pelas condições de declividade do relevo.

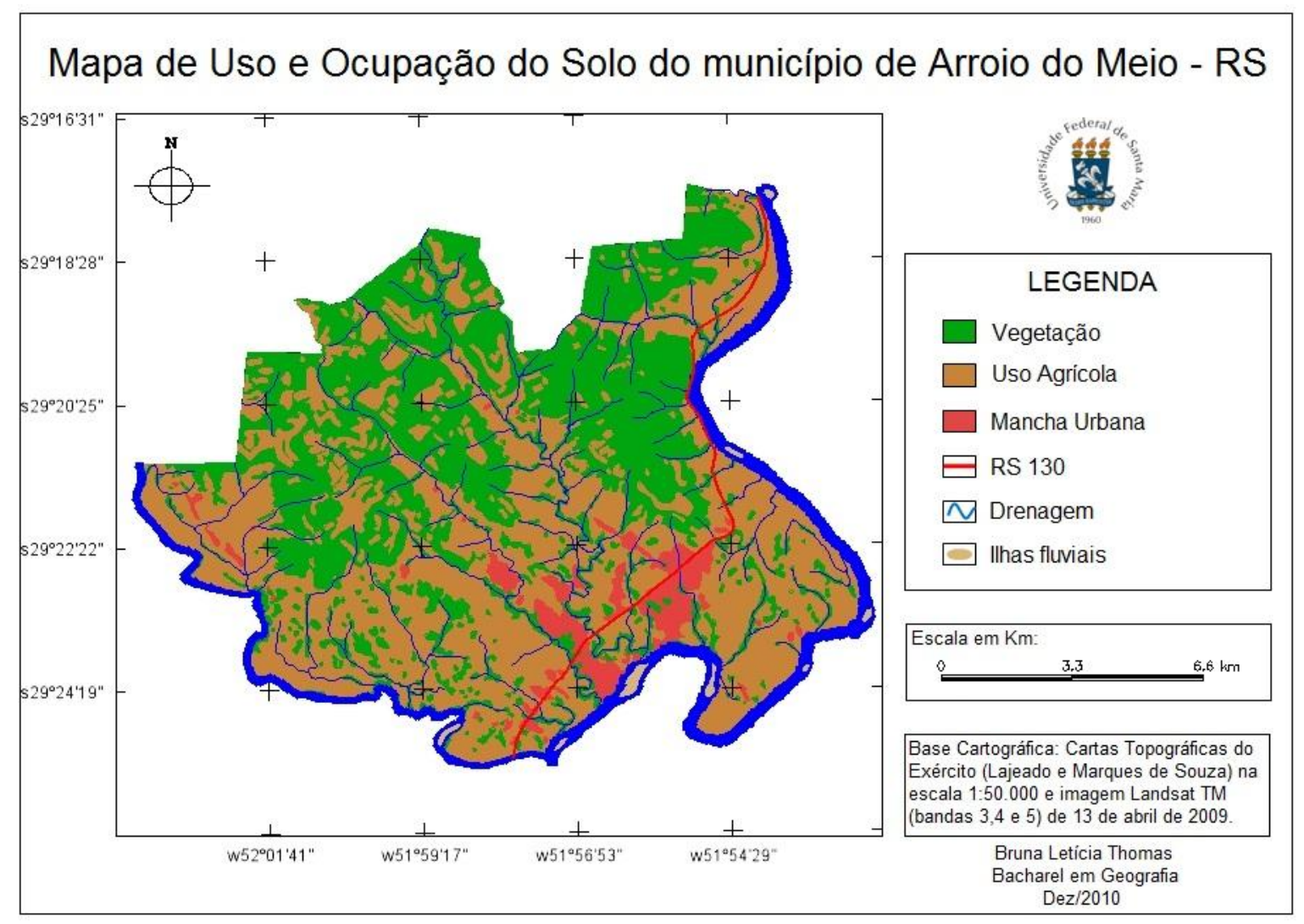

Mapa no 4: Mapa de Uso e Ocupação do Solo do município de Arroio do Meio, RS.

Elaboração: THOMAS, B. L., 2010.

Nas planícies de inundação dos rios Forqueta e Taquari e alguns outros arroios, o uso do solo por práticas agrícolas, principalmente cultivos de soja e milho, é intensivo, representando $49 \%$ ou $74,74 \mathrm{~km}^{2}$ do território municipal destinados a essa forma de utilização. Já o uso agrícola que ocorre nos patamares e topos de morros e encostas de menor declividade corresponde principalmente ao cultivo de milho e reflorestamento de eucalipto, equivalendo a $6,14 \%$ ou $9,37 \mathrm{~km}^{2}$ do município. Assim, no total, Arroio do Meio possui $55,14 \%$ do seu território com uso agrícola, o que equivale a $84,11 \mathrm{~km}^{2}$.

Nas áreas de morros de maior declividade, a vegetação nativa predomina, devido à dificuldade de acesso para uso da terra. A vegetação 
também está presente em alguns poucos remanescentes nas áreas de planície e margens de arroios e rios. Da área total do município, $60,8 \mathrm{~km}^{2}$ (ou $39,85 \%$ ) foram classificados como vegetação nativa, entretanto, como citado anteriormente, há possibilidade dessa classe ser menor devido dificuldade de visualização das áreas de reflorestamento de eucalipto.

A mancha urbana do município é a menor área, $6,87 \mathrm{~km}^{2}$ (equivalente a $4,5 \%$ do território municipal), e desenvolveu-se junto à RS 130 e às margens do rio Taquari e próximo aos arroios do Meio e Grande, em cota altimétrica entre 20 e 40 metros de altitude e, na sua maioria, em declividade de até $5 \%$, tornando essa área sujeita a processos de inundação.

O conhecimento da área de estudo e o auxílio do programa Google Earth facilitaram no processo de reconhecimento das classes temáticas durante seu processo de classificação visual. Cabe ressaltar, entretanto, que a vegetação ciliar, ou seja, de margens de arroios e rios, foi de difícil interpretação de sua situação em alguns pontos da imagem. Este fato se deve por ser uma vegetação pouco densa em vários lugares, ou seja, possuindo pixeis de tons claros e de difícil distinção.

Identificação de áreas de incompatibilidade legal das Áreas de Preservação Permanente (APPs) dos recursos hídricos do município

Em relação às áreas de incompatibilidade legal das APPs de recursos hídricos, destaca-se que os locais onde mais se encontram usos em espaços legalmente protegidos são em cotas altimétricas de até 100 metros de altitude, onde também se situam as menores declividades e, portanto, áreas mais propícias ao uso agrícola. Essa situação pode ser explicada pelo pequeno tamanho das propriedades rurais do município, em média 10,9 hectares (BDR, 2003, p.10), provocando a busca pela máxima exploração da terra e, assim, havendo o desrespeito à legislação ambiental. A situação de algumas APPs onde ocorre o uso agrícola pode ser visualizada na figura abaixo (nำ2): 


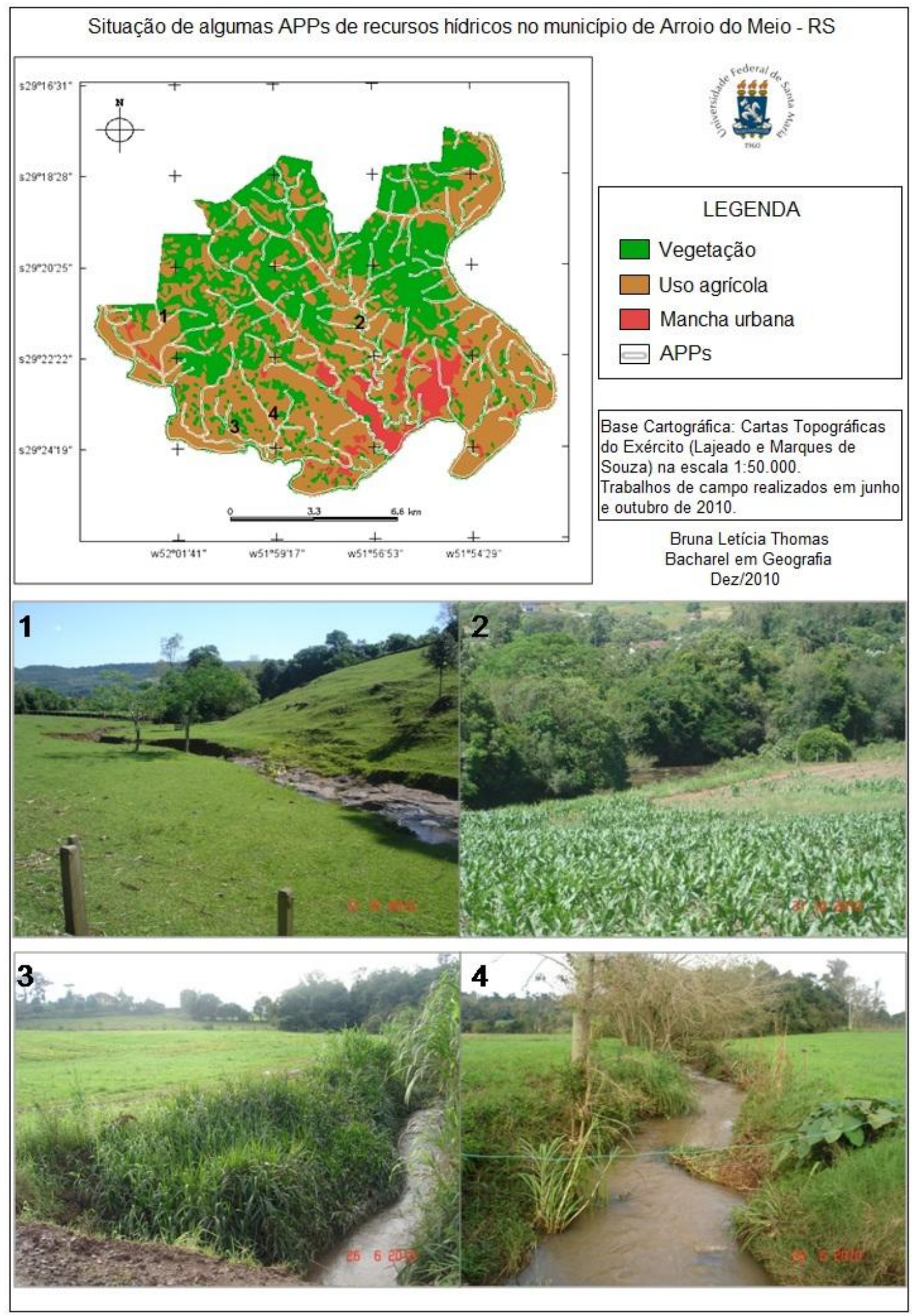

Figura n²: Situação de algumas APPs de recursos hídricos do município de Arroio do Meio, RS.

Fonte: Trabalho de campo, junho e outubro de 2010. 
Em maiores altimetrias e declividades, na porção ao norte do município, é onde se encontra a maior área de vegetação do município, o que acaba por resultar em APPs de melhor estado de conservação e, portanto, recursos hídricos mais conservados, apesar de ainda haver a ocorrência de exceções.

$\mathrm{Na}$ mancha urbana, as APPs sofrem com uma urbanização já consolidada, principalmente às margens dos arroios do Meio e Grande e rio Taquari. Essa ocupação é considerada regular pelo artigo $9^{\circ}$ da resolução $\mathrm{n}^{\circ}$ 369/2006 do CONAMA, que prevê a possibilidade de supressão ou intervenção de vegetação de APP para regularização fundiária, portanto não podem ser consideradas áreas de uso conflitantes com a legislação ambiental de APPs. Porém, a questão do descarte irregular do lixo e ausência de esgotamento sanitário é presente, principalmente às margens do rio Taquari e parte do arroio do Meio, onde vivem famílias de menores condições e renda.

\section{A PROPOSTA DE ZONEAMENTO AMBIENTAL PARA O MUNICÍPIO DE ARROIO DO MEIO}

Como já citado anteriormente, os critérios avaliados para a proposição das zonas foram geomorfologia (neste caso, as características de declividade), condições gerais dos recursos hídricos, cobertura vegetal existente, aglomerações urbanas, intervenções antrópicas e condições gerais das APPs (na medida em que eram identificadas áreas de incompatibilidade legal). No processo de avaliação para o estabelecimento das zonas, notou-se que os referidos critérios estão diretamente integrados às características de declividade, como por exemplo: as áreas com declividade de até $5 \%$ são onde se encontram os usos agrícolas mais intensivos e as condições gerais dos recursos hídricos e APPs são de significativa degradação, ou seja, presença de áreas de incompatibilidade legal.

A Zona de Interesse de Proteção Ambiental (Fotografia oㅜ 2) ficou estabelecida na porção do município que apresentou características de maior preservação dos recursos florestais, aliado a declividades acentuadas (grande 
maioria acima de $12 \%$ de declive), presença de aproximadamente 16 nascentes de recursos hídricos preservadas e poucas áreas com intervenções antrópicas de uso agrícola. Sendo assim, cerca de 7,04\% do território municipal foram destinadas à máxima proteção.

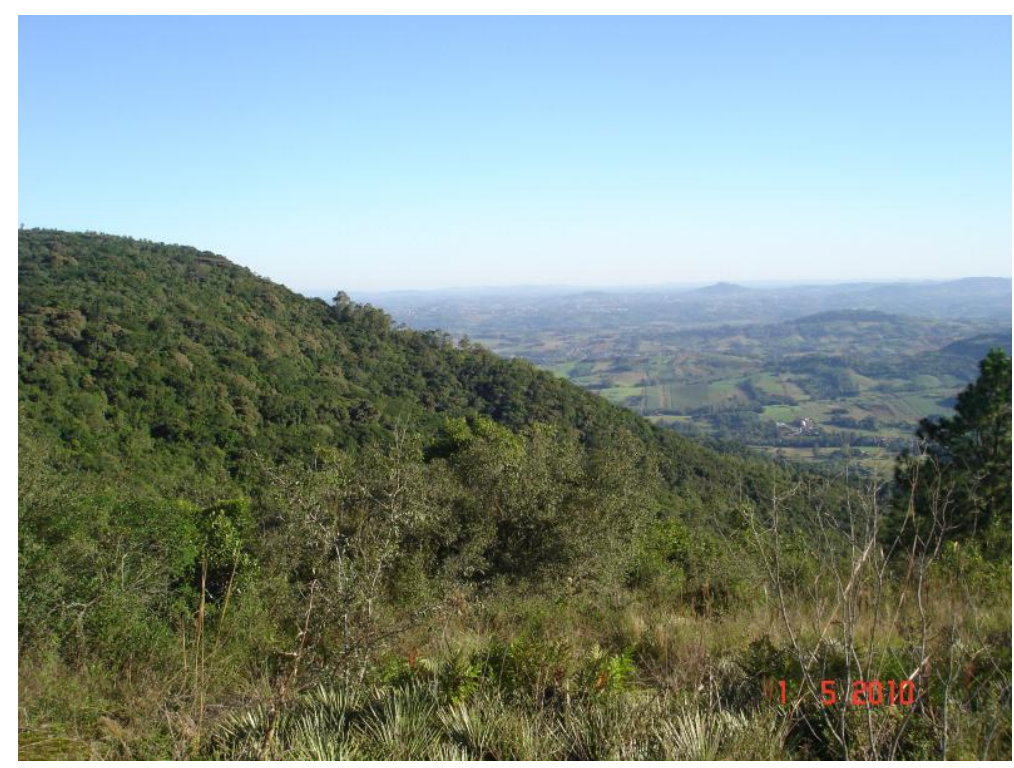

Fotografia no 2: vista parcial da Zona de Interesse de Proteção Ambiental. Fonte: THOMAS, B.L. Passeio ao morro Gaúcho, maio de 2010.

À Zona de Interesse de Controle Ambiental (Fotografia no 3) couberam as áreas onde se apresenta um mosaico de usos agrícolas e de remanescentes florestais, totalizando $32,8 \%$ do território municipal $\left(50,04 \mathrm{~km}^{2}\right)$. Em relação às APPs desta zona, algumas se encontram preservadas e outras não, o que potencializa a importância de enquadrá-las em interesse de controle ambiental, visando proteger o que ainda não está degradado e, também, procurar a recuperação das que necessitarem. 


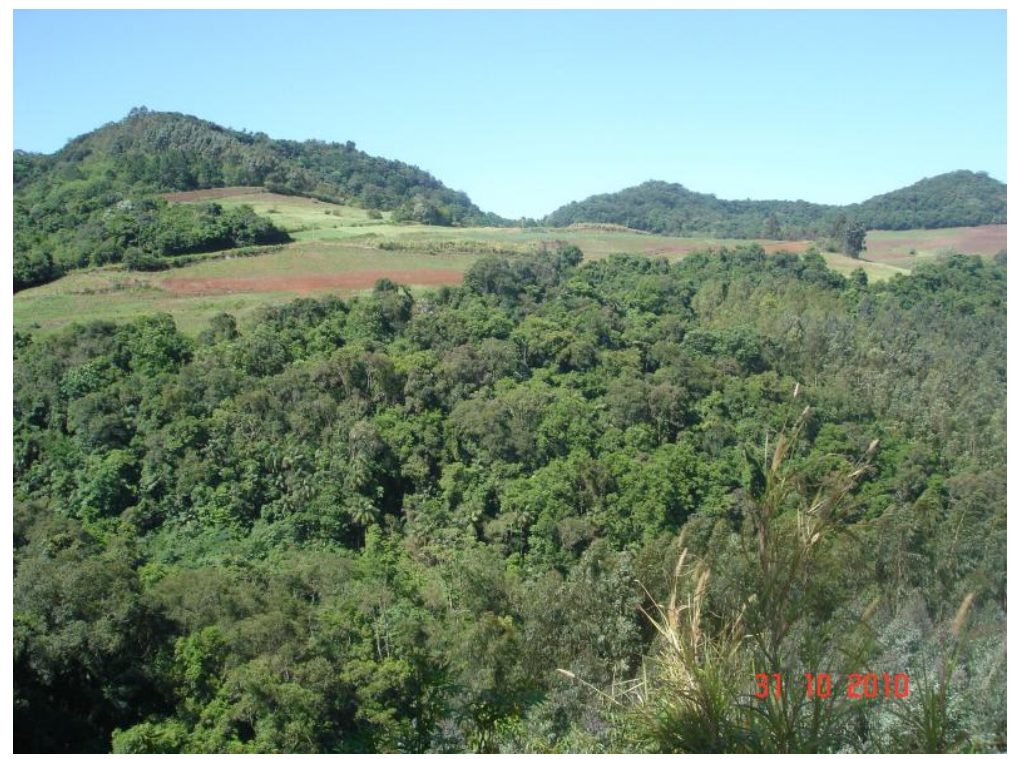

Fotografia no 3: Área situada na Zona de Interesse de Controle Ambiental.

Fonte: THOMAS, B.L. Trabalho de campo, outubro de 2010.

A Zona de Interesse de Reabilitação Ambiental é a maior do município, equivalendo a $84,9 \mathrm{~km}^{2}$ ou $55,66 \%$ do território. Apresentam áreas onde as declividades propiciam o uso agrícola intenso do solo, o que resultou em APPs e suas respectivas drenagens bastante degradadas. Portanto, o interesse na reabilitação destas áreas visa às melhorias das condições ambientais. Algumas pequenas manchas urbanas também se enquadraram nessa área, devido suas características menos impactantes.

A Zona de Interesse de Adequação Ambiental é a de menor proporção (6,84 $\mathrm{km}^{2}$ ou $4,48 \%$ da área total municipal) e ficou estabelecida nas manchas urbanas próximas à RS 130. Estas se caracterizam por usos urbanos mais intensos, como indústrias de grande, médio e pequeno porte, estabelecimentos comerciais e de serviços, residências e também, expansões de loteamentos urbanos residenciais.

A proposta de zoneamento ambiental para o município de Arroio do Meio pode ser visualizada no mapa $\mathrm{n}^{\circ} 5$. 


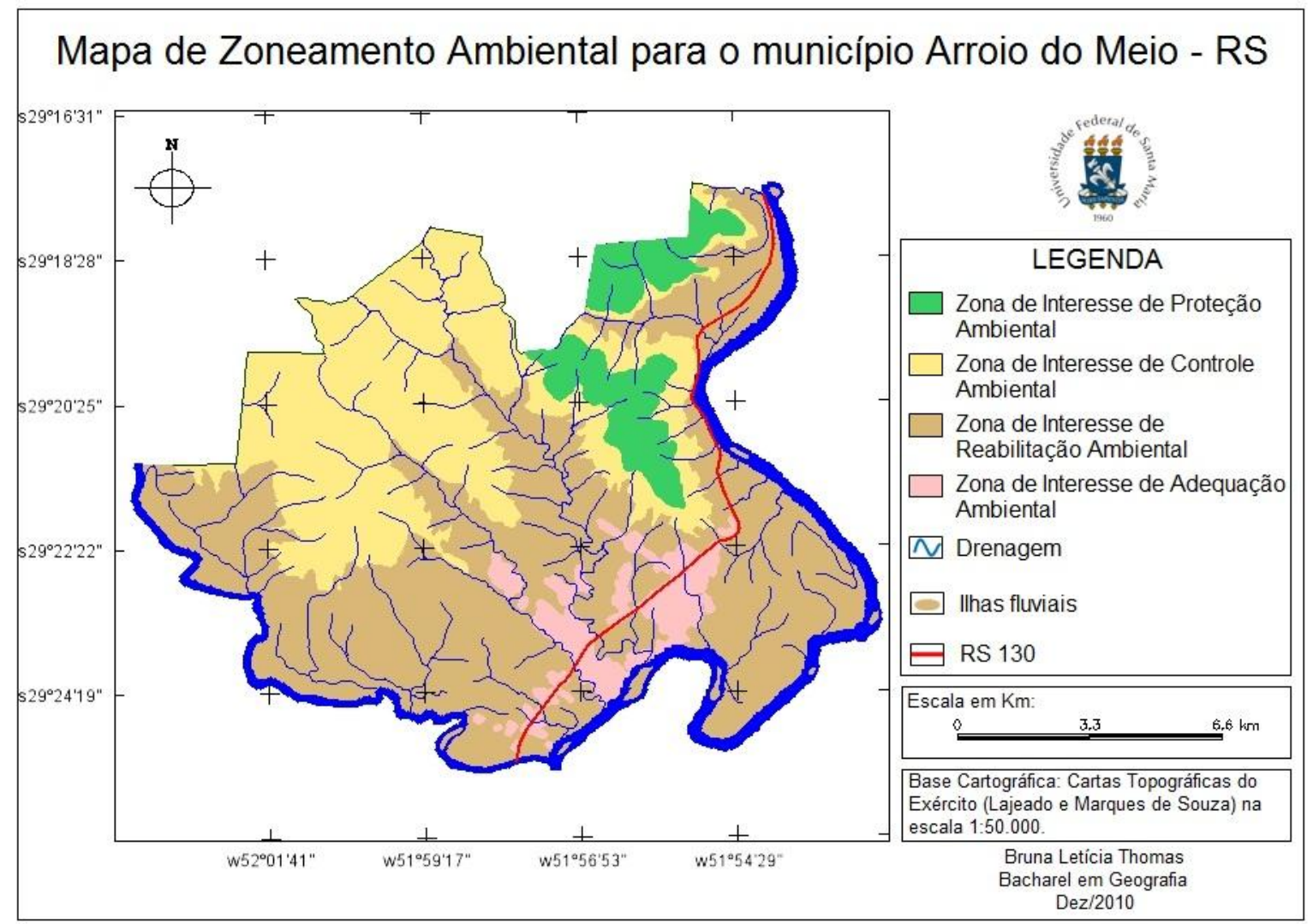

Mapa no 5: Mapa de Zoneamento Ambiental para o município de Arroio do Meio, RS.

Elaboração: THOMAS, B. L., 2010.

Finalizado esse processo de delimitação das zonas, algumas ações devem ser pensadas visando colocar em prática os objetivos de cada unidade de zoneamento. Como exemplo, podemos citar a criação de uma Unidade de Conservação na Zona de Interesse de Proteção Ambiental, já que a mesma objetiva a máxima proteção dos atributos ambientais presentes na área. $O$ aprofundamento acerca das ações para cada zona deverá levar em consideração fatos e políticas de âmbito local e regional e, também, exemplos de ações realizadas em outros lugares. A proposição destas ações terá continuidade em um próximo estudo.

\section{CONSIDERAÇÕES FINAIS}

O zoneamento ambiental, visto como um instrumento de ordenamento territorial que objetiva o desenvolvimento sustentável e racional, é um 
importante aliado aos governos federais, estaduais e municipais, principais responsáveis em garantir um espaço ecologicamente equilibrado à população. O zoneamento permite conhecer os atributos ambientais da área de estudo, contribuindo para que o seu planejamento busque minimizar os impactos existentes $\mathrm{e}$ indique caminhos para o desenvolvimento com qualidade ambiental e, consequentemente, qualidade de vida aos cidadãos.

Considerando as características físico-naturais e o processo de ocupação e uso do solo de Arroio do Meio e as intenções de políticas governamentais que podem a vir a intensificar esse modo de apropriação (por exemplo, o RUMOS 2015), a proposição de um zoneamento ambiental buscou contribuir para que o crescimento municipal ocorra de forma ordenada e racional, respeitando os condicionantes ambientais e os usos já consolidados nesse espaço.

Cabe lembrar que os limites estabelecidos para cada zona neste trabalho não devem ser considerados rígidos, imutáveis. Trata-se de propostas, indicações iniciais, que podem e devem ser reavaliadas, tanto para a criação de novas zonas ou mudança de limites das já estabelecidas, assim como também, a adoção de outros critérios de avaliação e incorporação de novas informações para auxiliar nessa reavaliação das zonas e aprofundamento do trabalho. Além disso, a presente pesquisa buscou contribuir ao servir como base para o início de uma discussão no município, que deve repensar seu espaço geográfico e a forma como o vem ocupando e utilizando.

\section{REFERÊNCIAS}

ARROIO DO MEIO. Lei n. 916, de 27 de maio de 1993. Autoriza o Poder Executivo Municipal a firmar Termo de Acordo para ajuste dos limites municipais e dá outras providências. PREFEITURA MUNICIPAL DE ARROIO DO MEIO, Arroio do Meio, RS, 27 maio 1993.

ARROIO DO MEIO, Lei n. 2.491, de 28 de dezembro de 2006. Dispõe sobre o parcelamento do solo urbano e dá outras providências. PREFEITURA MUNICIPAL DE ARROIO DO MEIO, Arroio do Meio, RS, 28 dez. 2006. 
BANCO DE DADOS REGIONAL - BDR. Programa de leite do Vale do Taquari: município de Arroio do Meio. UNIVATES. Lajeado, 2003.

BRANDT, A. Manual para o mapeamento de biótopos no Brasil: base para um planejamento ambiental eficiente. Fundação Alexander Brandt. Belo Horizonte, 1994.

BRASIL. Lei Federal n. 4.771, de 15 de setembro de 1965. Institui o novo Código Florestal. Presidência da República - Casa Civil, Brasília, DF, 15 de setembro de 1965.1 Disponível em: $<$ http://www.planalto.gov.br/ccivil 03/Leis/L4771.htm>. Acesso em: 28 out. 2010.

. Lei Federal n. 6.938, de 31 de agosto de 1981. Dispõe sobre a Política Nacional do Meio Ambiente, seus fins e mecanismos de formulação e aplicação, e dá outras providências. Presidência da República - Casa Civil, Brasília, DF, 31 ago. $1981 . \quad$ Disponível em: $<$ http://www.planalto.gov.br/ccivil 03/Leis/L6938.htm>. Acesso em: 11 maio 2010.

Decreto Federal n. 4.297, de 10 de julho de 2002. Regulamenta o art. 9을 inciso II, da Lei $n^{\circ} 6.938$, de 31 de agosto de 1981, estabelecendo critérios para o Zoneamento Ecológico-Econômico do Brasil - ZEE, e dá outras providências. Presidência da República - Casa Civil, Brasília, DF, 10 jul. 2002.

Disponível em: $<$ http://www.planalto.gov.br/ccivil 03/decreto/2002/D4297.htm>. Acesso em: 11 maio 2010.

CARTA GEOMORFOLÓGICA Caxias do Sul. Ministério do Planejamento, Orçamento e Gestão, Diretoria de Geociências, 2003. Escala 1: 250.000.

CARTA TOPOGRÁFICA Lajeado. Ministério do Exército, Diretoria de Serviço Geográfico, 1980. Escala 1:50.000.

CARTA TOPOGRÁFICA Marques de Souza. Ministério do Exército, Diretoria de Serviço Geográfico, 1980. Escala 1:50.000.

CONSELHO NACIONAL DO MEIO AMBIENTE - CONAMA (Brasil). Resolução n. 369, de 28 de março de 2006. Dispõe sobre os casos excepcionais, de utilidade pública, interesse social ou baixo impacto ambiental, que possibilitam a intervenção ou supressão de vegetação em Área de Preservação Permanente-APP. Brasília, DF, 28 mar. 2006. Disponível em: < http://www.cidades.gov.br/secretarias-nacionais/programasurbanos/legislacao/regularizacaofundiaria/CONAMA RES CONS 2006 369.pdf>. Acesso em: 16 nov. 2010.

DE BIASE, M. A carta clinográfica: os métodos de representação e sua confecção. Revista do departamento de Geografia. USP, 1992, p. 45 - 60 
ERSE, E. B.; PHILOMENA, A. L. Comentários sobre a utilização de roteiros metodológicos de planejamento ambiental na composição de sistemas sócioeconômicos de natureza sustentável. Revista Internacional de Ciencia y Tecnología de la Información Geográfica, n. 5, 2005. Disponível em: <http://geofocus.rediris.es/2005/Informe6 2005.pdf>.Acesso em: 13 ago.2010.

GOVERNO DO ESTADO DO RIO GRANDE DO SUL. Secretaria da Coordenação e Planejamento. RUMOS 2015: estudo sobre o desenvolvimento regional e logística de transportes no Rio Grande do Sul. Porto alegre: SCP, 2006, 5v. p. 298.

INSTITUTO BRASILEIRO DE GEOGRAFIA E ESTATÍSTICA. IBGE - Instituto Brasileiro de Geografia e Estatística. Brasília, 2007. Disponível em: $<$ http://www.ibge.gov.br/cidadesat/historicos cidades/historico conteudo.php?c odmun=430100 >. Acesso em: 6 abr. 2010.

INSTITUTO BRASILEIRO DE GEOGRAFIA E ESTATÍSTICA. IBGE - Instituto Brasileiro de Geografia e Estatística. Brasília, 2010. Disponível em: $<$ http://www.censo2010.ibge.gov.br/dados divulgados/index.php?uf=43>.

Acesso em: 19 nov. 2010.

INSTITUTO NACIONAL DE PESQUISAS ESPACIAIS-INPE. Sistema de Processamento de Informações Georreferenciadas. São José dos Campos, 1991. Versão 5.0.6. Sistema Operacional: Windows 95/98/ME/NT/XP/Vista.

ROSS. J. L. S. Geomorfologia: ambiente e planejamento. São Paulo: Ed. Contexto, 2003.

SANTOS, M. R. R.dos. Critérios para análise do zoneamento ambiental como instrumento de planejamento e ordenamento territorial. $2010.128 \mathrm{f}$. Dissertação (Mestrado em Ciências da Engenharia Ambiental) - Universidade de São Paulo, São Carlos, 2010.

SANTOS, R. F. dos. Planejamento Ambiental: teoria e prática. São Paulo: Oficina de textos, 2004.

SOBREIRA, F.G. Estudo geoambiental do Conselho de Sesimbra. 1995. 347 f. Tese (Doutorado na Faculdade de Ciências) - Universidade de Lisboa, Lisboa, 1995.

SOUZA, L. A. de. Diagnóstico do meio físico como contribuição ao ordenamento territorial do município de Mariana (MG). 2004. 182 f. Dissertação (Mestrado em Engenharia Civil) - Universidade Federal de Ouro Preto, Ouro Preto, 2004. 